\title{
HIPERREALITAS KONSUMSI TANDA DAN MAKNA PADA TRENDING FASHION JILBAB OLEH MAHASISWI
}

\author{
Fifi Rachmawati Alfi'ah', Abdul Rahman'", Okta Hadi Nurcahyono ${ }^{3}$ \\ ${ }^{1}$ Universitas Sebelas Maret Surakarta, INDONESIA \\ ${ }^{2}$ Universitas Sebelas Maret Surakarta, INDONESIA \\ ${ }^{3}$ Universitas Sebelas Maret Surakarta, INDONESIA \\ *Correspondence: $\square$ abdul.rahman@ @staff.uns.ac.id
}

\begin{abstract}
The study objective is to examine the excessive consumption of jilbab fashion trends by university students. This research is a descriptive study with qualitative methods and determined informants using purposive sampling. The researchers use primary and secondary both data all were collected through interviews, observation, and documentation. After the data were triangulated by sources and methods then we analyzed data using the simulakra theory of Jean P. Baudrillard to see the excessive consumption of jilbab fashion trends by students. The main results indicate that the growing jilbab fashion trends through social media have made student's experience enjoy excessive consumerist behavior for many years. Most female students imitate the public figures as their role models. They admire female fashion models having full of signs and meanings hence they reproduce signs and meaning for their own interests. They become addicted to buying the latest hijab fashion products regardless of either using it or selling it. They keep uploading their own photos wearing the most current fashion in Instagram. It seems that they create an uncertainty either the use of fashionable jilbab recommended by religion or promoting them as commercial products in social media.
\end{abstract}

\begin{abstract}
Abstrak
Penelitian ini untuk mengkaji konsumsi yang berlebih terhadap trend fashion jilbab yang dilakukan oleh mahasiswi UNS. Penelitian ini merupakan sebuah penelitian deskriptif dengan menggunakan metode kualitatif dan dalam menentukan informan digunakan purposive sampling. Peneliti menggunakan sumber data sumber primer dan sekunder. Data dikumpulkan melalui metode wawancara, observasi, dan dokumentasi. Data yang sudah terkumpul kemudian dilihat keabsahannya menggunakan triangulasi sumber dan metode untuk mendapatkan data yang valid. Data dianalisis menggunakan teori simulacra dari Jean Baudrillard untuk melihat konsumsi berlebih atas tren fashion jilbab yang dilakukan oleh mahasiswi UNS. Hasil dari penelitian ini menunjukkan bahwa, perkembangan trend fashion jilbab melalui media sosial membuat mahasiwi mengalami perilaku konsumtif yang berlebihan. Melalui media sosial, mahasiswi meniru para public figure yang dijadikannya panutan. Tampilan yang penuh tanda dan makna kemudian di reproduksi oleh mahasiswi sehingga mereka semakin candu dalam membeli produk fashion jilbab terbaru tanpa lagi memikirkan nilai gunanya. Universitas kini menjelma menjadi tempat penuh pengakuan atas eksistensi dan status dengan mengunggahnya ke instagram pribadinya. Hal seperti ini membuat kekaburan antara penggunaan jilbab yang dianjurkan agama dengan tampilan yang dimunculkan dalam sosial media.
\end{abstract}

\section{Article History}

Received: 11-10-2020,

Revised: 30 -12-2020,

Accepted: $31-12-2020$

Keywords:

Fashion;

Hiperreality;

Jilbab;

Trends; 


\section{A. Pendahuluan}

Jilbab di Indonesia mengalami berbagai perkembangan sebagai fenomena yang penuh akan makna religius. Menurut data yang dimiliki oleh Badan Pusat Statistik indonesia, hasil sensus penduduk pada tahun 2010 menunjukkan jumlah penduduk Indonesia yang memeluk agama Islam sebanyak 237,641,326 orang yang setara dengan 87,18\%. ${ }^{1}$ Melihat dari data tersebut, sudah barang tentu fenomena penggunaan jilbab tidak asing lagi bagi masyarakat Indonesia. Keberadaan jilbab di Indonesia tidak serta merta dapat diterima secara gamblang oleh pemerintahan kala itu. Penggunaan jilbab di Indonesia sendiri mulai marak digaungkan sepanjang tahun 1990-an dimana para mahasiswi dari kampus-kampus kota besar melakukan demonstrasi mengenai pelarangan penggunaan jilbab bagi mahasiswi maupun siswa sekolah, sehingga hal inilah yang disebut menjadi cikal bakal popularitas jilbab mulai lebih dikenal. ${ }^{2}$ Saat ini hampir setiap hari kita menjumpai perempuan menggunakan jilbab dengan berbagai model dan bentuk baik di public space, sekolah, kantor hingga universitas. Berdasarkan data milik Financial Times, di Indonesia sendiri pada tahun 2016 terdapat sekitar 10\% perempuan yang mengenakan jilbab dengan 50\% para pengguna jilbab tersebut memiliki rata-rata umur 20 tahun. ${ }^{3}$

Secara epistemologi, jilbab berasal dari kata Jalaba atau Jalabib yang berarti pakaian penutup seluruh tubuh dari ujung kepala hingga mata kaki, seperti baju yang dipakai ketika hujan, pakaian yang digunakan tidak menerawang serta tidak memperlihatkan lekuk tubuhnya. ${ }^{4}$ Sedangkan dalam buku Hirasatul Fadhilah, Syaikh Bakar Zaid menjelaskan jilbab merupakan pakaian tebal yang menutupi seluruh tubuhnya hingga tidak lagi terlihat perhiasan yang mereka gunakan. ${ }^{5}$ Perintah penggunaan jilbab terdapat di surat Al-Ahzab ayat 59 yang berbunyi :

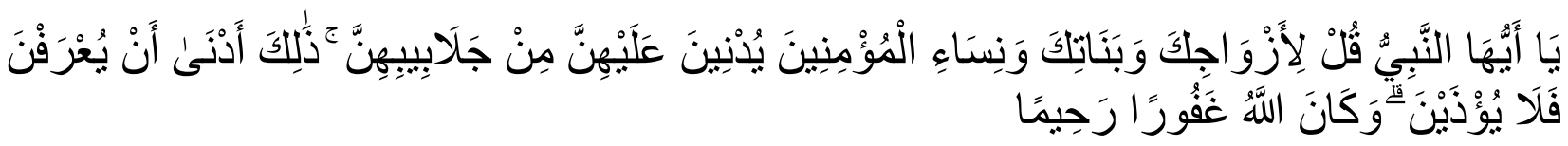

Yang artinya : Wahai Nabi! Katakanlah kepada istri-istrimu, anak-anak perempuanmu dan istri-istri orang mukmin, "Hendaklah mereka menutupkan jilbabnya ke seluruh tubuh mereka." Yang demikian itu agar mereka lebih mudah untuk dikenali, sehingga mereka tidak diganggu. Dan Allah Maha Pengampun, Maha Penyayang. ${ }^{6}$

Fakta dalam kehidupan di masyarakat menunjukan prilaku berjilbab yang berbeda. Banyak perempuan muslimah mengenakan jilbab, akan tetapi belum sesuai dengan pengertian (aturan) yang ditetapkan oleh agama Islam. Alasannya masyarakat muslimah ingin jilbab modern, sesuai dengan mode dan tren yang sedang berkembang saat ini. Jilbab menjadi trending fashion. Hal ini menyebabkan jilbab menjadi komoditas ekonomi yang diminati oleh banyak orang. Menurut The State of Global Islamic Economy Report pada tahun 2018-2019 menunjukkan Indonesia menempati

1 "Sensus Penduduk 2010 - Penduduk Menurut Wilayah dan Agama yang Dianut | Indonesia," BPS, accessed December 31, 2020, http://sp2010.bps.go.id/index.php/site/tabel?tid=321.

2 Eveline Ramadhini, "Jilbab sebagai Representasi Simbolik Mahasiswi Muslim di Universitas Indonesia," MASYARAKAT: Jurnal Sosiologi, August 22, 2017, hlm: 84, https://doi.org/10.7454/mjs.v22i1.6835.

${ }^{3}$ Izzarine Nurdiaz Pramudita, Muhammad Edy Susilo, and Christina Rochayanti, "Analysis Of Signs And Meanings In Sariayu Hijab Haircare Advertisements (Semiotic Analysis of Instagram Account @sariayuhijab)” 10, no. 2 (2017): hlm: 95.

${ }^{4}$ Prof Dr H. Nasaruddin Umar, Ketika Fikih Membela Perempuan (Jakarta: Elex Media Komputindo, 2014), hlm: 40.

5 Rahima Sikumbang Sarmadi, Haramkah Cadar?: Dinamika Pemahaman Pemakaian “Cadar” di Kampus (Yogyakarta: Gre Publishing, 2018), hlm: 15.

6 Al-Qur'an: 33 (59) 
posisi kedua negara yang mengembangkan fashion muslim terbaik di dunia setelah Uni Emirat Arab. ${ }^{7}$

Kebiasaan penggunaan jilbab yang dahulunya merupakan fenomena yang penuh dengan nuansa religius akan keyakinan dan pegangan hidup sehingga dianggap sebagai tradisi islam, mulai bergeser menjadi fenomena fashion masa kini sebagai bagian dari gaya hidup. ${ }^{8}$ Menurut penelitian yang berjudul Empowerment Model for the People Living with HIV/AIDS (PLWHA) in Surakarta, Central Java- Indonesia diketahui bahwa jilbab dipakai oleh wanita penderita HIV/AIDs sebagai upaya taubat kepada Allah dan memudahkan diterima oleh warga tetangga dan masyarakat, dan meningkatkan kepercayaan diri saat periksa dan berobat rutin di Puskesmas. ${ }^{9}$ Jilbab kini digunakan sebagai bahasa yang menyampaikan pesan-pesan modernitas. Agama dan perempuan seolah-olah bergabung membanngun budaya populer sebagai akibat konsumsi terhadap fashion jilbab masa kini. Perkembangan media massa dan informasi digadang-gadang menjadi faktor utama fashion jilbab mampu menyebar keseluruh penjuru tempat.

Masyarakat yang dulunya hanya memakai pakain-pakaian sederhana, mulai dimasuki dengan model-model jilbab yang beragam dan modis sesuai dengan perkembangan jaman. Penggambaran produk dengan spektakuler yang dilakukan oleh para kapital, mampu menarik keinginan konsumsi masyarakat yang menyebabkan masyarakat kini memiliki tipe ideal jilbab mereka sendiri sesuai dengan apa yang mereka lihat di media. Identitas diri seseorang sudah tidak lagi ditentukan oleh orang itu sendiri, melainkan dibangun atas dasar keberbauran antara tanda, citra dan kode. Kehidupan dikendalikan oleh jaring-jaring tanda yang tidak dapat dihindarkan kembali menyebabkan simulasi kini telah menggantikan representasi atas kenyataan. ${ }^{10}$ Simulasi ini dianggap merupakan dampak dari kemajuan penemuan manusia dibidang reproduksi suatu objek dan teknologi informasi.

Secara khusus fenomena penggunaan jilbab di universitas negeri menjadi sangat menarik, karena saat ini banyak dijumpai mahasiswi yang menggunakan jilbab walaupun tidak ada peraturan yang mewajibkannya baik dalam menghadiri perkuliahan ataupun dalam kehidupan sehari-harinya. Penggunaan jilbab yang dilakukan oleh mahasiswi biasanya digabungkan dengan mode berbusana yang kekinian sehingga membuat universitas seolah-olah menjadi ruang pengakuan atas konsumsi tanda terhadap fashion dan gaya hidup. Penggunaan jilbab yang sekarang menjadi tempat interpretasi penuh makna dan kode mendorong generasi saat ini menganggap seseorang yang menggunakan jilbab tidak lagi sebagai seorang yang kaku dan hanya memikirkan agama saja, melainkan sebagai sebuah simbol kecantikan seorang perempuan tanpa harus meninggalkan ajaran agamanya serta syarat akan pengakuan dari orang lain. Hal tersebut menyebabkan konsumsi seseorang terhadap fashion jilbab menjadi tidak masuk akal lagi.

Perilaku konsumtif seseorang terhadap fashion saat ini dilakukan tanpa adanya pertimbangan nilai guna atau faktor kebutuhannya. Kegiatan konsumsi bukan lagi fokus terhadap kebutuhan hidup akan tetapi untuk mendapatkan prestige atau nilai tanda. Pergeseran makna dari nilai guna menjadi nilai tanda, atau tidak lagi memperhatikan manfaat atau fungsi akan tetapi lebih fokus kepada nilai simbol. Fenomena ini menghasilkan simularka berupa realitas pergeseran nilai guna menjadi nilai tanda. $^{11}$

\footnotetext{
${ }^{7}$ Bambang Irianto, “Indonesia Siap Menjadi Kiblat Fesyen Muslim Dunia”, Gema, no. 65 (April-Juni 2019)

${ }^{8}$ Atik Catur Budiati, "Jilbab: Gaya Hidup Baru Kaum Hawa,” The Sosilogi of Islam 1, no. 1 (2011): hlm: 63.

9 Abdul Rahman et al., "Empowerment Model for the People Living with HIV/AIDS (PLWHA) in Surakarta, Central Java- Indonesia," International Medical Journal 24, no. 03 (2019): hlm: 380.

${ }^{10}$ Alo Liliweri, Prasangka, Konflik, dan Komunikasi Antarbudaya (Jakarta: Prenada Media, 2018), hlm: 143.

11 Riska Nur Diana, "Gaya Hidup Konsumtif Mahasiswa Fakultas Ilmu Sosial Dan Hukum Unesa Akibat Adanya Online Shop Jilbab," Kajian Moral dan Kewarganegaraan 2, no. 4 (May 19, 2016): hlm: 691, https://jurnalmahasiswa.unesa.ac.id/index.php/jurnal-pendidikan-kewarganegaraa/article/view/15170.
} 
Penelitian yang dilakukan oleh Nur Ratih Devi Affandi terhadap Bandung Hijabers Community menunjukkan bahwa anggota dalam memutuskan untuk menggunakan jilbab atas dasar kesadaran diri atas perintah agama maupun pengaruh oleh lingkungan keluarga yang islami. Mereka memutuskan untuk bergabung ke dalam komunitas tersebut karena merasa lebih nyaman apabila belajar agama bersama dengan kaum muda. Jilbab yang digunakan oleh anggota Bandung Hijabers Community ini kemudian dijadikan gaya hidup dengan menampilkan identitas diri dan nilai dalam balutan tren. ${ }^{12}$ Tourmalina Tri Nugraheni dalam penelitiannya menyingkap mekanisme tanda dibalik hiperrealitas tren hijab terhadap majalah fashion Femina dihasilkan bahwa dalam menggunakan jilbab, seseorang akan memaknai jilbabnya secara berbeda-beda melalui lima struktur triadik. Menurut Peirce, sebuah tanda dibentuk melalui hubungan segitia atau triadic relation yang artinya tanda (representamen) selalu berhubungan dengan objek yang diacunya. Dalam struktur triadik pertama dan kedua, pemaknaan terhadap jilbab masih berpedoman pada hakikat jilbab yang sebenarnya yang termuat di dalam Al-Quran maupun Hadits sehingga belum terlihat adanya simulasi terhadap jilbab. Kemudian pada struktur triadik ketiga, simulasi terhadap jilbab mulai nampak melalui selendang yang mulai berkembag pada tahun 1996. Selanjutnya pada struktur triadik keempat, makna jilbab sebagai penutup kepala sudah tidak lagi menjadi fokus perhatian, namun jilbab ditampilkan melalui tunik dan gamis sebagai penutup aurat dan pada struktur dan pada struktur triadik ke lima kata hijab mulai muncul menggantikan jilbab sebagai kata penutup aurat melalui fashion Summer Hijab. Penggunaan semiotic Pierce melibatkan 3 titik yakni representamen $(\mathrm{R})-\operatorname{Object}(\mathrm{O})$ - Interpretant $(\mathrm{I})$ sehingga jilbab dapat menjadi tempat pencitraan yang tepat. ${ }^{13}$

Penentuan seseorang dalam menggunakan jilbab model tertentu ternyata dipengaruhi oleh lingkungan sekitar orang tersebut. Hal ini selaras dengan penelitian yang dilakukan pada mahasiswi UGM mengenai jilbab sebagai identitas organisasi Islam oleh Qowim Mustofa. Dikatakannya bahwa jilbab kini menjadi realitas sosial yang tidak hanya soal teologi saja, namun memuat permasalahan-permasalahan yang lebih kompleks. Organisasi yang diikuti memiliki pengaruh besar terhadap pemilihan model jilbab oleh anggotanya sehingga jilbab dijadikan tempat pembentukan jati diri yang sesungguhnya. ${ }^{14}$ Kemudian dalam penelitian yang dilakukan oleh Middya Boty terhadap mahasiswi psikologi UIN Raden Fatah Palembang menunjukkan bahwa jilbab dimaknai berbeda-beda oleh para mahasiswi dan tidak lagi dipandang sebagai simbol ketakwaan. Jilbab lalu dimaknai sebagai simbol identitas, gaya hidup, status sosial, kepribadian dan ketentraman hati sebagai dampak dari fashion yang telah menjadi imajinatif. ${ }^{15}$

Berpijak dari beberapa penelitian terdahulu, kebanyakan dari tulisan tersebut berfokus kepada pemaknaan terhadap jilbab sebagai bentuk kemajuan fashion sehingga menjadikan jilbab tidak lagi sekedar penanda agama pada seseorang. Perbedaan tulisan ini dengan penelitian sebelumnya adalah subjek yang dijadikan penelitian kebanyakan merupakan komunitas jilbab yang pada dasarnya memang berfokus dan tertarik kepada dunia fashion secara lebih mendalam ataupun mahasiswi pada universitas swasta yang memang diwajibkan menggunakan jilbab, sedangkan kali ini peneliti

12 NurRatih Devi Affandi, "Hijab Sebagai Gaya Hidup (Studi Fenomenologi Tentang Motif Perempuan Memakai Hijab Dan Aktivitas Dalam Media Sosial Intagram),” Jurnal Retorika 9 (July 25, 2017): 49-64.

13 Tourmalina Tri Nugrahenny, "Menyingkap Mekanisme Tanda di Balik Hiperrealitas Tren Hijab (Analisis Semiotika pada Fenomena Tren Hijab),” Jurnal Komunikasi Indonesia 5, no. 1 (January 3, 2018): 16-28, https://doi.org/10.7454/jki.v5i1.8317.

${ }^{14}$ Qowim Musthofa, “Jilbab Sebagai Identitas Organisasi Islam Di Perguruan Tinggi," Wawasan: Jurnal Ilmiah Agama Dan Sosial Budaya 2, no. 2 (December 30, 2017): 143-55, https://doi.org/10.15575/jw.v2i2.1680.

${ }^{15}$ Midya Boty, “Makna Jilbab Gaul,” Jurnal Ilmu Agama: Mengkaji Doktrin, Pemikiran, Dan Fenomena Agama 18, no. 1 (June 30, 2017): 19-32, https://doi.org/10.19109/jia.v18i1.1535. 
menjadikan mahasiswi pada universitas negeri yang tidak ada paksaan dalam menggunakan jilbab. Perbedaan selanjutnya adalah jika penelitian sebelumnya berfokus pada pemaknaan yang diberikan oleh subjek terhadap jilbab masa kini, maka dalam artikel ini akan berfokus pada bentuk konsumsi dilakukan oleh para mahasiswi sehingga mendorong mereka membangun prestise diri.

Penelitian ini bertujuan untuk menjelaskan bentuk konsumsi tanda yang dilakukan oleh mahasiswi di Universitas Sebelas Maret Surakarta mengenai trend fashion jilbab masa kini, melihat bahwa UNS sendiri memiliki mahasiswa Islam yang lebih banyak. Dari hasil survey yang dilakukan oleh peneliti secara acak terhadap 8 responden yang berasal dari fakultas yang berbeda terlihat bahwa mahasiswi yang beragama Islam namun tidak menggunakan jilbab hanya sebesar $6.1 \%{ }^{16}$

\section{B. Metode Penelitian}

Artikel ini menggunakan menggunakan metode penelitian kualitatif dengan pendekatan deskriptif. ${ }^{17}$ Sumber data yang digunakan dalam artikel ini adalah data primer yang diperoleh langsung dari informan mahasiswi UNS serta pedagang jilbab di sekitar UNS. Peneliti menggunakan 3 teknik pengumpulan data yakni wawancara, observasi, dan dokumentasi. Data hasil wawancara, observasi dan dokumentasi dianalisis dengan langkah Miles dan Huberman, pengumpulan data, reduksi data, sajian data dan penarikan kesimpulan. ${ }^{18}$

\section{Pembahasan atau Analisis}

\section{Pandangan Mahasiswi Universitas Sebelas Maret terhadap Jilbab}

Jilbab menjadi salah satu objek fashion yang memiliki dampak sosial, budaya dan ekonomi secara luas dalam kehidupan mahasiswi dari masa ke masa. Sebelum fashion menargetkan jilbab untuk dipopulerkan, dahulu jilbab dimaknai dengan sederhana dan apa adanya sebagai bentuk nyata pelaksanaan perintah Islam dari Allah. Jilbab saat ini tidak memerlukan waktu lama untuk menjadi barang komoditas fashion yang senantiasa mengeluarkan gaya atau model baru. Perkembangan jilbab seperti ini tidak mengherankan dan akan mempengaruhi pola pakaian dan perilaku muslimah muda dan mereka secara kreatif akan mengartikan jilbab sesuai dengan apa yang mereka serap. Perbedaan pendapat mengenai pemaknaan jilbab bagi masing-masing muslimah merupakan hal yang wajar. Berdasarkan hasil wawancara serta observasi, peneliti menemukan empat pandangan positif mengenai jilbab yakni penutup aurat, penjaga perilaku, identitas muslimah, dan pelindung diri. Pada saat yang sama, peneliti menemukan satu pandangan negatif jilbab sebagai beban agama untuk mahasiswi muslimah yang belum sepenuhnya siap berjilbab.

\section{a. Jilbab Sebagai Penutup Aurat}

Menutup aurat dengan jilbab merupakan perintah yang diberikan Allah bagi para perempuan penganut agama Islam. Keharusan ini diberikan langsung melalui Al-Quran maupun Hadits sebagai kitab penuntun umat muslim. Pemaknaan terhadap jilbab juga dipengaruhi oleh pengetahuannya mengenai jilbab. Pengetahuan mengenai hukum dan syarat penggunaan jilbab hanya diketahui sedikit oleh informan mahasiswi, yakni penggunaan hingga menutup dada dan tidak menyerupai punuk unta. Hal tersebut membuat mahasiswi memandang jilbab hanya merupakan sebuah penutup aurat. Berjilbab merupakan tindakan nyata atas perintah wajib bagi para perempuan yang harus dijalani, walaupun

\footnotetext{
${ }^{16}$ Hasil Survey yang dilaksanakan peneliti pada tanggal 27 Februari 2020

${ }^{17}$ Albi Anggito Setiawan Johan, Metodologi penelitian kualitatif (CV Jejak (Jejak Publisher), 2018).

${ }^{18}$ John W. Creswell, Research Design: Qualitative, Quantitative, and Mixed Methods Approaches (California:
} SAGE, 2014) 
hanya dimaknai sebagai penutup aurat mereka tetap menggunakan jilbab hingga saat ini dan enggan untuk melepaskannya.

\section{b. Jilbab Sebagai Penjaga Perilaku}

Jilbab tidak hanya dimaknai oleh mahasiswi sebagai perintah agama saja, melainkan sebagai penjaga perilaku. 3 dari 10 informan, memandang jilbab bukan hanya sekedar melaksanakan perintah agama saja. Orang-orang dianggap tidak dapat mengatur orang lain untuk memakai jilbab, karena sesungguhnya penampilan bukan semata-mata mencerminkan perilaku pemakainya. Yang harus diperhatikan dalam menggunakan jilbab tidak hanya sebatas fisiknya saja yang tertutup, akan tetapi harus diikuti dengan perilaku istiqomah oleh pemakainya. Dengan mengontrol hawa nafsu dianggap akan mampu membuat seseorang menjadi pribadi yang lebih baik dan mampu menjaga diri dari perbuatan yang tidak baik.

\section{c. Jilbab Sebagai Identitas Muslimah}

Dalam kehidupan sosial warga kampus, mahasiswi membutuhkan identitas yang jelas sebagai seorang mahasiswi. Hal ini mendorong mahasiswi memiliki pandangan berbeda mengenai jilbab. Penggunaan jilbab yang sudah diajarkan orang tua kepada 6 orang (60\%) informan sedari kecil menjadikan mereka sadar bahwa menutup jilbab merupakan sebuah keharusan bagi seorang muslimah sehingga mereka tidak pernah sekalipun melepas jilbab hingga kini, karena jika melepaskannya mereka akan merasa berdosa karena telah melanggar perintah agama. Penggunaan jilbab ini menjadikan informan lebih mendekatkan diri kepada tampilan Islami yang kemudian menjadikannya sebagai sebuah ciri diri. Jilbab dipandang mampu mampu membentuk identitas seseorang. Identifikasi terhadap orang tua, kakak perempuan, dan orang-orang di lingkungan sekitar menjadi salah satu faktor yang menentukan bagaimana informan mahasiswi ingin dipandang sebagai seorang muslimah dengan jilbab yang ia kenakan.

\section{d. Jilbab Sebagai Pelindung Diri}

Di Universitas Sebelas Maret jumlah mahasiswi lebih banyak dari pada mahasiswa, namun hal itu tidak menjamin keamanan dan kenyamanan mahasiswi baik di dalam kampus maupun di luar kampus. Sebagai perempuan $20 \%$ informan memandang jilbab sebagai sebuah pelindung diri. Informan $\mathrm{AFH}$ dan $\mathrm{HN}$ mengungkapkan bahwa sebelum ia memutuskan untuk memakai jilbab, mereka sering menggunakan pakaian-pakaian ketat yang sering membuatnya mendapat godaan dari laki-laki. Jilbab menurut HN sebuah perintah yang diberikan oleh agama untuk menutup dada dan bahu, tidak menerawang sehingga hal ini menghindarkan dari pakaian-pakaian haram, walaupun dalam kenyataannya jilbab yang digunakan $\mathrm{HN}$ masih belum bisa dikatakan syar'i. ${ }^{19}$ Keputusan untuk menggunakan jilbab yang dilakukan oleh informan mahasiswi mampu membuat dirinya lebih merasa aman dan nyaman karena nilai-nilai religiusitas yang melekat dalam jilbab mampu menghindarkannya dari godaan-godaan yang ia terima sebelumnya.

\section{e. Jilbab Untuk Menghindari Stereotip Syar'i}

Pemikiran bahwa menggunakan jilbab sesuai dengan aturan agama akan membuat penggunanya memikul beban religiusitas yang diberikan kepada orang-orang pengguna jilbab syar'i juga membuat 3 dari 10 dari informan belum siap berjilbab seutuhnya. Mereka sebenarnya memiliki pengetahuan cukup mengenai hukum dan syarat penggunaan jilbab masih memilih untuk menggunakan jilbab-jilbab yang sesuai dengan tren walaupun

${ }^{19}$ Wawancara dengan Informan HN, Mahasiswi UNS pada tanggal 30 Mei 2020 pukul 18.13 WIB 
mengesampingkan nilai agama yang terkandung dalam tren tersebut. Para informan memutuskan belum bisa menggunakan jilbab syar'i karena ia menganggap orang yang menggunakan jilbab syar'i harus dibarengi dengan perilaku-perilaku religius lainnya yang mana ini belum ada pada dirinya. Pandangan-pandang seperti ini membuat mahasiswi seringkali lebih memilih untuk mengikuti tren jilbab yang dapat menjadikannya tetap cantik walaupun dibalut dengan jilbab dan tidak harus terlalu menjaga perilakunya. Label yang diberikan masyarakat yang menuntut pengguna jilbab syar'i harus memiliki sesuai dengan ajaran-ajaran agama membuat mahasiswi ini enggan menggunakannya dengan dalih belum sepenuhnya siap untuk melaksanakan syariat agama disegala aspek kehidupan.

\section{Konsumsi Jilbab oleh Mahasiswi Universitas Sebelas Maret}

Sosial media menjadi salah satu alasan konsumsi berada. Berbagai jenis media social sosial mampu mendorong seseorang untuk menjelajah informasi dari berbagai negara dan sumber, sehingga segala macam hal akan dapat ditampilkan melalui layar gawai. Konsumsi akan semakin meningkat karena produk-produk akan mudah diakses dan dilihat oleh siapa saja. Penawaran atas gaya jilbab yang dilakukan oleh para influencer juga menyebabkan konsumsi terhadap gaya itu sendiri menjadi semakin luas. Peneliti menemukan beberapa cara konsumsi jilbab yang dilakukan mahasiswi UNS demi tercapainya pengakuan diri, yakni :

Tabel 1. Bentuk Konsumsi Mahasiswi UNS terhadap Jilbab

\begin{tabular}{lll}
\hline No. & Cara & Bentuk Konsumsi \\
\hline 1. & $\begin{array}{l}\text { Menirukan fashion public } \\
\text { figure }\end{array}$ & $\begin{array}{l}\text { Membeli produk serupa yang dikenakan oleh public } \\
\text { figure. }\end{array}$ \\
2. & $\begin{array}{l}\text { Mengikuti tren fashion } \\
\text { popular luar negeri }\end{array}$ & $\begin{array}{l}\text { Mengikuti dan membeli jilbab yang sedang populer di } \\
\text { negara lain yakni Turki dan Maroko. }\end{array}$ \\
& Abstrak. \\
Menghindari stereotip syar'i & $\begin{array}{l}\text { Membeli jilbab sesuai dengan tren yang sedang } \\
\text { berkembang karena jilbab konvensional dianggap } \\
\text { mengandung nilai agama yang kental dan dianggap } \\
\text { belum mampu mencerminkan perilakunya saat ini. }\end{array}$ \\
& Takut berbeda dengan orang \\
lain & $\begin{array}{l}\text { Tidak menggunakan model jilbab yang sudah } \\
\text { ketinggalan jaman dan menggantinya dengan model } \\
\text { jilbab masa kini. }\end{array}$ \\
\hline
\end{tabular}

Kegiatan konsumsi atas fashion jilbab yang dilakukan oleh mahasiswi Universitas Sebelas Maret ini selaras dengan teori simulacra menurut Jean Baudrillard. Situasi saat ini yang menjadikan jilbab sebagai gaya hidup baru dipengaruhi oleh perkembangan teknologi telah mendorong masyarakat menjadi semakin konsumtif. Fashion jilbab saat ini yang mengalami perkembangan pesat menghasilkan berbagai macam gaya dan model yang ditawarkan melalui toko-toko di pusat perbelanjaan ataupun toko online sehingga menyebabkan konsumsi atas tren menjadi tak terkendali. Baudrillard mengungkapkan bahwa masyarakat saat ini sudah memasuki era postmodern yang dicerminkan oleh masyarakat Barat dimana mereka mengalami produksi, komunikasi, serta konsumsi yang dipraktekkan secara berlebihan melalui iklan yang ditampilkan pada media. 
Kemunculan para public figure yang memutuskan menggunakan jilbab dalam berkarir menghasilkan idola-idola baru dengan kesan yang lebih religius namun tetap modern dapat dikonsumsi oleh para mahasiswi melalui berbagai sosial media. Masyarakat yang semakin modern mendorong lahirnya perilaku konsumtif, dengan kata lain konsumsi menjadi hal yang sangat penting bagi kehidupan manusia. ${ }^{20}$ Pola pikir konsumsi mulai dijalankan dimana produksi dan tanda yang melekat lebih penting dibandingkan kegunaannya. Orang-orang akan mulai mengidentifikasikan dirinya dengan barang-barang yang telah ia konsumsi sehingga pemikiran seperti ini digunakan untuk membangun logika pembeda dalam menentukan gaya hidup dan nilai yang disesuaikan dengan milik orang lain. Situasi inilah yang kemudian disebut dengan simulakra yang merupakan cara pemenuhan masyarakat modern atas tanda dari sebuah objek konsumsi.

Bagi mahasiswi yang berkuliah di Universitas Sebelas Maret, fenomena penggunaan jilbab sudah tidak lagi hanya dimaknai sebagai penanda nilai religius saja, melainkan sudah menjadi salah satu bagian dari kebutuhan dan gaya hidup. Perubahan pandangan dan penggunaan jilbab disebabkan oleh keikutsertaan mereka ke dalam arus tren fashion yang tengah berkembang di masyarakat. Dari 10 mahasiswi yang menjadi informan, 9 dari mereka mengikuti tren jilbab secara lebih mendalam agar tidak ketinggalan jaman. Penerimaan atas fashion jilbab yang sedang berkembang di masyarakat ini membuat mahasiswi memiliki perubahan pandangan dalam pemaknaan jilbab. Nilai-nilai religius yang terkandung didalam sebuah jilbab sudah tidak terlalu dianggap penting. Contohnya, ada 9 informan yang mengikuti tren fashion jilbab mengaku tidak terlalu mengerti akan hukum dan syarat dalam penggunaan jilbab yang tercantum didalam Al-Quran maupun Hadits. Dasar pengertian mengenai syarat pakain dan penggunaan jilbab mereka hanya sebatas wajib menutup seluruh aurat dengan menggunakan pakaian yang tidak tembus pandang dan kerudung menjulur hingga dada. Hanya ada 1 orang informan yang mengetahui dengan baik tentang hukum dan syarat penggunaan.

Secara rasional, mahasiswi memilih jenis jilbab yang ingin mereka gunakan. Ketidaktahuan dengan pasti mengenai nilai agama yang menjadi pegangan dan dasar dalam pemakaian jilbab ini menyebabkan mahasiswi mudah terpengaruh akan objek konsumsi yang bahkan tidak sesuai dengan nilai agama. Salah satu informan yakni RA mengaku tidak suka menggunakan gamis dalam rok untuk kegiatan sehari-hari dan lebih memilih menggunakan kerudung pashmina, kaos atau blus serta celana, padahal salah satu syarat penggunaan jilbab adalah tidak memperlihatkan lekuk tubuhnya.

Kreasi fashion jilbab yang dianggap menguntungkan dijadikan lahan bisnis oleh para produsen. Realitas baru mulai dibangun dengan tujuan menggeser nilai luhur sesungguhnya melalui kegiatan konsumsi. Fashion kontemporer saat ini mulai menawarkan realitas sebagai sebuah tanda dari suatu objek. ID sebagai penjual jilbab dengan sengaja melakukan endorsement kepada selebgram agar menjadi sebuah tren dan produknya mampu terjual. ${ }^{21}$

Fashion jilbab kini memadukan kesan cantik dan syar'i.Penggunaan model-model jilbab yang cantik dan sempurna digunakan untuk membangun realitas baru tentang kata cantik namun tetap sesuai dengan ajaran agama. Realitas dimanipulasi dengan menjadikannya indah sehingga mampu mempengaruhi kesadaran konsumen akan hasrat konsumsi. Hal ini menjadikan orangorang memiliki representasi masing-masing atas dasar realitas yang ada. Semua informan mahasiswi mengaku memiliki role model dalam menentukan gaya berpakaiannya. Selebgram

${ }^{20}$ Muryanti, Perempuan Pedesaan: Kajian Sosiologis Pekerja Rumah Tangga (Yogyakarta: Omah Nusantara, 2012).

${ }^{21}$ Wawancara dengan Informan ID, Penjual jilbab pada tanggal 24 April 2020 pukul 9.14 WIB 
yang dijadikan rujukan ini merupakan sebuah citraan yang sengaja dibangun untuk mengaburkan realitas sesungguhnya. Standar kecantikan muslimah yang baru mulai terbangun melalui tampilan para artis maupun selebgram yang digambarkan apik sehingga memunculkan fenomena penuh popularitas.

Memakai jilbab juga digunakan untuk membangun citra Muslimah. Selebgram yang dijadikan rujukan ini merupakan sebuah pencitraan yang sengaja dibangun untuk mengaburkan realitas sesungguhnya. Standar kecantikan muslimah yang baru mulai terbangun melalui tampilan para artis maupun selebgram yang digambarkan dengan elegan agar memunculkan fenomena penuh popularitas sehingga menirukan adalah tepat dalam memakai fashion jilbab. Keinginan untuk tampil menyerupai Nadhia Arini, Sonia, dan Annisa menyebabkan WN sering membuat jilbab sendiri dengan mengikuti gaya yang ditampilkan oleh selebgram tersebut. Penggunaan yang trendi namun masih tetap menutup aurat menjadi alasan utama WN meniru gaya tersebut. $^{22}$

Selain WN, informan ZK yang merupakan penyuka musik K-Pop juga membeli baju-baju yang bisa dipadu-padankan dengan kerudung namun memiliki style ala Korea setelah terkesan dengan tampilan para idol tersebut melalui media sosial yang diikutinya. ${ }^{23}$ Tumbuhnya keinginan agar terlihat mirip ini merupakan sebuah realitas palsu. Mereka menganggap bahwa akan terlihat sama jika menggunakan model atau gaya yang sama pula. Pemikiran seperti ini membuat seseorang akan membangun logika pembeda dalam menentukan nilai dan model jilbab yang disesuaikan dengan milik orang lain. Citraan ini sengaja dilaksanakan agar rasional seseorang dapat dipaksakan seolah-olah kewajiban yang harus dipenuhi. Pemaksaan ini kemudian menjadikan seseorang menginginkan sebuah objek konsumsi tanpa adanya relasi dengan kebutuhan itu sendiri. Fashion kini menjelma menjadi komoditas yang penuh akan citra atau tanda.

Tanda yang melekat didalam sebuah objek fashion mampu menggantikan realitas yang sesungguhnya. Pemilihan model jilbab yang hendak digunakan FA dengan pertimbangan tidak membuat kulit menjadi hitam ataupun tidak terlihat gemuk menggambarkan FA ingin menunjukkan suatu kesan atas apa yang ia kenakan. ${ }^{24}$ Kemudian ketidaksukaan HN atas penilaian temannya tentang gaya yang ia pakai membuatnya lebih berhati-hati dalam menentukan apa yang akan ia kenakan. Tanda yang terkandung dalam suatu komoditas akan terus dipertahankan dengan mengkonsumsinya.

Menurut Baudrillard, kode telah mengaburkan antara realitas dan citra dengan menampilkan realitas-realitas palsu sebagai sesuatu yang nyata. ${ }^{25}$ Hubungan objek telah mengubah manusia sebagai sesuatu yang dikontrol oleh tanda atau tanda tertentu. Fungsi dari objek yang dikonsumsi bukan terletak pada kegunaannya, melainkan pada nilai simbol dan nilai tanda untuk mengejar hasrat akan kehormatan dan pengakuan diri atas orang lain. Mengkonsumsi model jilbab terbaru membuat AH merasa dianggap sama dengan teman-temannya satu fakultas. ${ }^{26}$ Keinginan $\mathrm{AH}$ untuk bisa merasa nyaman ketika berada di lingkungan perkuliahan ini mendorong dirinya untuk menggunakan jilbab. Kode-kode ini juga berperan sebagai bahasa dan penanda $\mathrm{AH}$ akan eksistensi diri. Informan lainnya yakni RA yang memiliki pekerjaan sebagai freelancer model juga membuatnya harus mempertahankan citra sebagai seorang model

\footnotetext{
${ }^{22}$ Wawancara dengan Informan WN, Mahasiswi UNS pada tanggal 29 April 2020 pukul 12.44 WIB

${ }^{23}$ Wawancara dengan Informan ZK, Mahasiswi UNS pada tanggal 16 April 2020 pukul 16.30 WIB

${ }^{24}$ Wawancara dengan Informan FA, Mahasiswi UNS pada tanggal 30 April 2020 pukul 13.44 WIB

${ }^{25}$ Brian Gogan, Jean Baudrillard: The Rhetoric of Symbolic Exchange (USA: SIU Press, 2017), hlm: 52.

${ }^{26}$ Wawancara dengan Informan AH, Mahasiswi UNS pada tanggal 1 Mei 2020 pukul 08.13 WIB
} 
melalui konsumsi terhadap trend fashion jilbab. Keinginan tampil cantik seperti layaknya seorang model membuat RA harus bisa memviralkan melalui unggahan fotonya di instagram pribadi.

Tanda-tanda yang telah ditanamkan di dalam objek konsumsi sebelumnya kini telah bermetamorfosis menjadi sistem prestise dan klasifikasi status didalam masyarakat. Sesuai dengan penuturan OA, para mahasiswi di Fakultas Ilmu Sosial dan Ilmu Politik (FISIP) telah dilabeli sebagai fakultas dengan mahasiswinya yang stylish dan gaul memang coba terus dihidupkan oleh teman-temannya. ${ }^{27}$ Stereotip yang diberikan oleh mahasiswa lain diluar FISIP membuat banyak teman-temannya mengikuti model-model yang sedang populer. Keinginan untuk diakui sebagai salah satu mahasiswi FISIP membuat mereka melakukan praktek konsumsi terhadap nilai tanda dan nilai simbol tidak lagi diatur oleh dasar kegunaan, melainkan diatur oleh keinginan untuk mendapatkan status, identitas, kehormatan, atau bahkan mampu mempengaruhi perilaku melalui proses pemaknaan terhadap tanda atau simbol tersebut.

Peneliti juga menemukan ada sekitar 5 toko fashion jilbab yang berada di sekitar Universitas Sebelas Maret dengan display menarik sehingga mampu membuat para mahasiswi untuk datang dan membelinya. Model-model jilbab terkini yang ditawarkan oleh toko-toko tersebut menjadikannya sebagai lubang representasi yang salah. Kapitalisme ini telah mendorong mahasiswi untuk memilih secara bebas dan tak terbatas dengan hanya mengedepankan tanda yang terkandung. Informan ID dengan toko jilbab luniastore.id dan informan HV dengan toko jilbab online khalila hijab dan ayana hijab solo menawarkan berbagai macam produk dan model jilbab dengan segala visualisasi yang menarik. Keberbauran antara fakta, tanda dan kode yang berada dalam satu foto produk yang coba ditampilkan ID dan HV sehingga menjadikannya sebagai tempat praktek simulacra sebagai sebuah ruang yang syarat akan proses reduplikasi. ${ }^{28}$

Jilbab yang seharusnya menjadi representasi dari kehidupan beragama yang nyata saat ini telah menjadi realitas sendiri. Iklan-iklan fashion, serta foto-foto orang menggunakan fashion jilbab yang bertebaran di dalam media sosial telah menggantikan posisi nyata menjadi pokok utama reproduksi yang kemudian oleh Baudrillard disebut dengan fenomena hiperrealitas. Realitas-realitas baru yang penuh dengan rekayasa hadir untuk mengontrol logika dan perilaku. Para mahasiswi sebagai bentuk nyata masyarakat modern kini sedang berlomba-lomba untuk menampilkan gaya berbusana muslim yang tetap mengikuti tren karena dianggap memiliki nilai-nilai lain dari sekedar nilai religiusitas.

Keadaan simulasi bagi Baudrillard merupakan dampak dari kemajuan reproduksi manusia akan suatu objek dan teknologi. Media massa yang saat ini ada menjelma menjadi kenyataan membawa informasi-informasi untuk yang membentuk gaya hidup ataupun cara berpikir seseorang. Promosi yang sering ditawarkan para produsen fashion jilbab ini juga mendorong para mahasiswi informan untuk membeli. Hal-hal yang sebenarnya menjadi kebutuhan kemudian dikesampingkan dan terus menerus melakukan konsumsi seperti yang dilakukan OA. OA pernah membeli sebuah model jilbab karena tergiur dari promo yang sedang berlangsung di salah satu aplikasi belanja online padahal ia tidak terlalu membutuhkan. ${ }^{29}$ Harga-harga yang ditawarkan juga membuat rasionalitas para informan menjadi kabur sehingga menyebabkan

${ }^{27}$ Wawancara dengan Informan OA, Mahasiswi UNS pada tanggal 16 April pukul 16.10 WIB

28 Ach Mardani, "Praktik Konsumtif Mahasiswa Kangean di Surabaya (Kajian Simulakra, Simulasi dan Hiperrealitas J.P. Baudrillard)," Paradigma 2, no. 3 (August 20, 2014), https://jurnalmahasiswa.unesa.ac.id/index.php/paradigma/article/view/9071.

${ }^{29}$ Gogan, Jean Baudrillard. 
ketidakberdayaan informan menjadi semakin nyata. Hegemoni atas realitas ini kemudian menghasilkan budaya meniru sebagai bentuk nyata atas konsumsi yang dilakukan dalam sosial media.

Perkembangan sosial media menjadi tempat yang tepat dalam hiperrealitas. Berbagai model jilbab yang diunggah di dalam media sosial merupakan simulasi dengan menghilangkan fungsi sebenarnya dari sebuah jilbab. Jilbab ditunjukkan bukan semata-mata sebagai kain penutup tubuh, melainkan praktek aktualisasi dan eksistensi diri. Dalam keputusan untuk pembelian jilbab sendiri, informan akan melalui proses yang panjang. Pemilihan dengan seksama merk, model, bahan, dan warna menjadikannya sebagai media menunjukkan kelas, kemampuan ekonomi, hingga siapakah dirinya dengan mengambil segala konsekuensi, tak terkecuali mengeluarkan biaya yang banyak. Menurut informan WN, ia menyediakan biaya Rp. 500.000,- untuk sekali pembelian gamis. ${ }^{30}$ Kemudian RA menyediakan sebesar Rp. 150.000,dalam sekali pembelian. ${ }^{31}$ Pembelian akan produk-produk baru juga menjadi tidak masuk akal. HN mengungkapkan membeli produk fashion jilbab bisa hingga 6 kali dalam kurun waktu 4 bulan dan informan FA 2 hingga 3 kali dalam kurun waktu yang sama. Model jilbab yang dipilih pun harus sesuai dengan trend yang sedang berlangsung. Menurut penuturan ID dan HV sebagai penjual jilbab, kerudung pashmina beserta baju-baju potongan dengan moel tunik menjadi komoditas fashion yang sedang digandrungi oleh mahasiswi saat ini, sedangkan kerudung besar dan gamis lebih diminati oleh ibu-ibu. Beragamnya model jilbab yang sedang berkembang seperti kerudung bergo, pashmina, gamis, maupun pakaian dengan streetwear style membuat orang-orang memiliki beragam pilihan atas tampilan yang mereka inginkan.

Keinginan mereka untuk tetap mengikuti tren ini akhirnya menjadikannya sebagai tempat pembentuk identitas diri. Para informan mengaku suka mengunggah foto gambar diri ketika sedang melakukan suatu aktivitas. Dengan demikian, mereka memiliki pertimbangan matang dalam memilih foto yang akan diunggah dalam sosial media instagram yang dimiliki. ${ }^{32}$ Ekspektasi akan jumlah orang yang menyukai fotonya menjadi gambaran nyata akan eksistensi diri. Dari 10 informan, 8 diantaranya mengaku suka mengupload foto yang menampilkan fashion jilbab yang digunakan. Kegemaran para informan untuk bermain sosial media membuat mereka mengkonstruksi mana jilbab yang bagus dan mana model jilbab yang jelek. Kualitas dari produk itu sendiri kemudian diminati secara masif. Orang-orang akan meyakini bahwa yang nyata adalah apa yang kita tampilkan melalui media sosial dalam foto-foto yang diunggah saja sehingga hal tersebut menutupi nilai agama yang dimiliki.

Jilbab yang dianggap sebagai representasi kecantikan masa kini namun tetap dengan mengandung nilai religius. Perbedaan antara muslimah-muslimah yang dianggap kolot dan modern semakin memperlihatkan kekaburan akan status sosial yang bahkan tidak jelas asalusulnya. Kemudian pemilihan model jilbab yang disesuaikan dengan kondisi juga menunjukkan bahwa mereka sedang menegaskan keberadaan diri. Realitas utama jilbab sebagai simbol keagamaan perlahan-lahan memudar bahkan menghilang. Kenyataan tampilan yang diberikan oleh pengikut trend fashion jilbab yang tidak pernah ditampilkan merupakan hal yang berbeda dari fakta yang sesungguhnya. Penampilan yang selalu cantik inilah yang menjadi sebuah hiperrealitas. Manipulasi-manipulasi yang atas citra dan kode kemudian berhasil menguasai melalui proses simulasi.

\footnotetext{
${ }^{30}$ Wawancara dengan Informan WN, Mahasiswi UNS pada tanggal 29 April 2020 pukul 12.44 WIB

${ }^{31}$ Wawancara dengan Informan RA, Mahasiswi UNS pada tanggal 13 April 2020 pukul 18.30 WIB

${ }^{32}$ Wawancara dengan Informan LN, Mahasiswi UNS pada tanggal 24 April 2020 pukul 20.21 WIB
} 


\section{Kesimpulan dan Saran}

Perkembangan jilbab menjadi salah satu objek fashion menyebabkan jilbab kini menjadi salah satu komoditas yang selalu mengeluarkan model-model terbaru, sehingga hal ini dapat mempengaruhi pola pemikiran yang berbeda-beda mahasiswi. Beberapa dari mereka memandang bahwa jilbab merupakan penutup aurat yang wajib dilaksanakan oleh seorang muslimah. Selain itu, jilbab juga dimaknai sebagai penjaga perilaku karena jilbab tidak hanya perkara menutup tubuh saja, melainkan juga harus mampu menjaga hawa nafsu. Selanjutnya jilbab dianggap sebagai identitas diri seorang muslimah oleh beberapa mahasiswi. Dengan menggunakan jilbab, mereka mampu membangun identitas diri sebagai seorang yang modern tanpa harus meninggalkan perintah agamanya. Nilai-nilai agama yang melekat pada sebuah jilbab juga dianggap oleh beberapa mahasiswi sebagai sebuah beban religius sehingga mereka belum mau untuk menggunakan jilbab syar'i.

Perkembangan media sosial mendorong berbagai produk, gaya dan jenis jilbab menjadi sebuah tren kecantikan baru. Kemunculan para public figure yang selalu menampilkan jilbab dalam keadaan yang spektakuler mendorong mahasiswi memasuki keadaan simulasi. Para mahasiswi kemudian mereproduksi dengan memilih jilbab model-model tertentu yang sesuai dengan tren agar mereka terlihat sama dengan yang lainnya. Gaya berjilbab itu sendiri kemudian dikonstruksi melalui media sosial dengan unggahan foto model jilbab yang dilakukan oleh mahasiswi untuk menunjukkan eksistensi diri. Status sosial dan pengakuan atas diri ini merupakan suatu hal yang imajiner. Penampilan yang dipresentasikan pada kenyataannya bukan suatu kondisi yang nyata dan dianggap sebagai sebuah identitas diri muslimah baru. Nilai guna dikesampingkan, sedangkan citra diri diutamakan. Hal ini kemudian menunjukkan keberhasilan hiperrealitas dalam menciptakan realitas berpakaian cantik baru dengan embel-embel tanpa mengesampingkan nilai agama yang sesungguhnya melalui sebuah jilbab.

Bagi mahasiswi berhijab untuk lebih memaknai hijab secara benar, sehingga tidak salah dalam penggunaannya. Mengikuti perkembangan fashion harus disertai dengan kesadaran akan makna dari perilakunya. Harus dapat membedakan apa yang sebenarnya harus didahulukan, apakah nilai guna atau nilai tanda. Hal tersebut dilakukan guna mencegah penyimpangan makna dari hijab itu sendiri.

\section{E. Daftar Pustaka}

Affandi, NurRatih Devi. "Hijab Sebagai Gaya Hidup (Studi Fenomenologi Tentang Motif Perempuan Memakai Hijab Dan Aktivitas Dalam Media Sosial Intagram)." Jurnal Retorika 9 (July 25, 2017): 49-64.

Boty, Midya. “MAKNA JILBAB GAUL.” Jurnal Ilmu Agama: Mengkaji Doktrin, Pemikiran, Dan Fenomena Agama 18, no. 1 (June 30, 2017): 19-32. https://doi.org/10.19109/jia.v18i1.1535. Budiati, Atik Catur. "Jilbab: Gaya Hidup Baru Kaum Hawa." The Sosilogi of Islam 1, no. 1 (2011): 12.

Creswell, John W. Research Design: Qualitative, Quantitative, and Mixed Methods Approaches. California: SAGE, 2014.

Diana, Riska Nur. "Gaya Hidup Konsumtif Mahasiswa Fakultas Ilmu Sosial Dan Hukum Unesa Akibat Adanya Online Shop Jilbab.” Kajian Moral dan Kewarganegaraan 2, no. 4 (May 19, 2016). https://jurnalmahasiswa.unesa.ac.id/index.php/jurnal-pendidikankewarganegaraa/article/view/15170.

Gogan, Brian. Jean Baudrillard: The Rhetoric of Symbolic Exchange. USA: SIU Press, 2017.

Liliweri, Alo. Prasangka, Konflik, dan Komunikasi Antarbudaya. Jakarta: Prenada Media, 2018. 
Mardani, Ach. "Praktik Konsumtif Mahasiswa Kangean di Surabaya (Kajian Simulakra, Simulasi dan Hiperrealitas J.P. Baudrillard).” Paradigma 2, no. 3 (August 20, 2014). https://jurnalmahasiswa.unesa.ac.id/index.php/paradigma/article/view/9071.

Muryanti. Perempuan Pedesaan: Kajian Sosiologis Pekerja Rumah Tangga. Yogyakarta: Omah Nusantara, 2012.

Musthofa, Qowim. “Jilbab Sebagai Identitas Organisasi Islam Di Perguruan Tinggi." Wawasan: Jurnal Ilmiah Agama Dan Sosial Budaya 2, no. 2 (December 30, 2017): 143-55. https://doi.org/10.15575/jw.v2i2.1680.

Nugrahenny, Tourmalina Tri. "Menyingkap Mekanisme Tanda di Balik Hiperrealitas Tren Hijab (Analisis Semiotika pada Fenomena Tren Hijab)." Jurnal Komunikasi Indonesia 5, no. 1 (January 3, 2018): 16-28. https://doi.org/10.7454/jki.v5i1.8317.

Pramudita, Izzarine Nurdiaz, Muhammad Edy Susilo, and Christina Rochayanti. “Analysis Of Signs And Meanings In Sariayu Hijab Haircare Advertisements (Semiotic Analysis of Instagram Account@sariayuhijab)”10,no.2 (2017): 14.

Rahman, Abdul, Endang Sutisna Sulaeman, Slamet Riyadi, Yeremia Rante Ada, Fresthy Astrika, and Agus Eka Nurma Yuneta. "Empowerment Model for the People Living with HIV/AIDS (PLWHA) in Surakarta, Central Java- Indonesia." International Medical Journal 24, no. 03 (2019): 8.

Ramadhini, Eveline. "Jilbab sebagai Representasi Simbolik Mahasiswi Muslim di Universitas Indonesia.” MASYARAKAT: Jurnal Sosiologi, August 22, 2017, 81-103-103. https://doi.org/10.7454/mjs.v22i1.6835.

Sarmadi, Rahima Sikumbang. Haramkah Cadar?: Dinamika Pemahaman Pemakaian "Cadar" di Kampus. Yogyakarta: Gre Publishing, 2018.

BPS. "Sensus Penduduk 2010 - Penduduk Menurut Wilayah dan Agama yang Dianut | Indonesia." Accessed December 31, 2020. http://sp2010.bps.go.id/index.php/site/tabel?tid=321.

Setiawan, Albi Anggito, Johan. Metodologi penelitian kualitatif. CV Jejak (Jejak Publisher), 2018. Umar, Prof Dr H. Nasaruddin. Ketika Fikih Membela Perempuan. Jakarta: Elex Media Komputindo, 2014. 